\title{
Bioconcrete Technology and Neglected Biotoxicity
}

\author{
Galal Fares* \\ Department of Civil Engineering, King Saud University, Saudi Arabia
}

*Corresponding author: Galal Fares, Associate Professor, Center of Excellence for Concrete Research and Testing, Department of Civil Engineering, King Saud University, Riyadh 11421, Saudi Arabia.

To Cite This Article: Galal Fares. Bioconcrete Technology and Neglected Biotoxicity. Am J Biomed Sci \& Res. 2019 - 5(1). AJBSR.MS.ID.000874. DOI: 10.34297/AJBSR.2019.05.000874

Received: 制August 26, 2019; Published: 鮆 September 06, 2019

\begin{abstract}
Bioremediation of concrete durability issues becomes a new trend to revise and adopt. Bacteriology becomes an important branch of science in concrete applications. The use of nonpathogenic bacteria spores as microorganisms for biodeposition of calcite in concrete has been widely investigated. These microorganisms play same role as a self-healing agent, which has attracted the attention of several researchers while neglecting the biotoxicity side. Moreover, fewer have pointed at the provisions and precautions that should be applied to avoid "opportunistic pathogenic attacks" on living organisms within the boundaries of microbial concrete structures. The presence of bacteriologist is highly crucial for safe application of bioremediation of concrete properties. Limited applications are suggested.
\end{abstract}

\section{Introduction}

Concrete technology incorporates different techniques and adopts various applications. Concrete itself can be considered as alive structure whose properties develops over time and which also suffers like most living organisms from environmental variations, chemical and thermal effects. Hydration of cement in concrete is the main source of life-like properties in concrete; it is the spiritlike in living organisms. Taking care of cement "hydration health" and development is known as durability, which is considered as the keystone to success and full control of most of concrete properties. Other constituents such as minerals admixtures, aggregates and chemical admixtures play another important shield-like skeletal support to cement paste. Formulating constituents altogether in an optimized recipe leads to a durable stone-like creature i.e. a concrete structure that withstands many internal and external changes. However, the presence of real living organism becomes a promising and attractive approach. The inclusion of nonpathogenic bacteria spores becomes a new trend to repair occurring cracks in concrete i.e. they act as a self-healing agent in cementitious matrix [1-3]. However, an urgent question remains flashing on how dangerous are bioconcretes on public health. Few researchers highlighted this issue of toxicity and side effects of this technique. Do these concretes release toxic chemicals? If we follow the mechanism of bacteria action, the answer to this question will become obvious.

\section{Classifications of Bacteria}

(Figure 1)

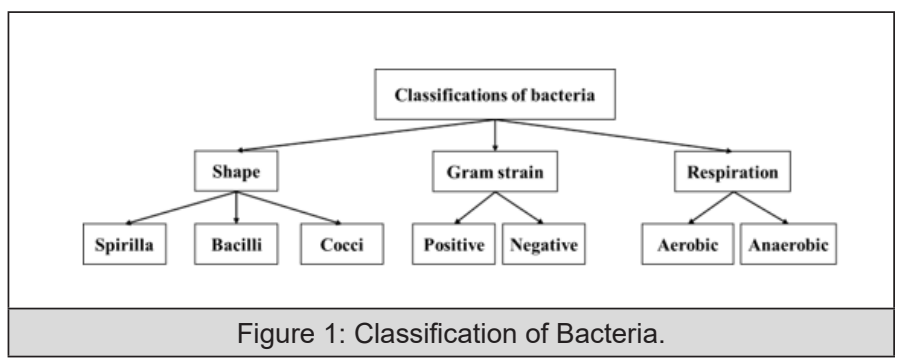

\section{Mechanism of Action}

As microorganisms, bacteria should be fed on nutrients to survive. In addition, they should have the ability to resist the elevated alkalinity in concrete. The presence of micropores are necessary for bacteria to dwell inside and avoid high stresses, which are already available in concrete. The bio-geochemical process which induces the precipitation of calcite in concrete cracks are identified as a microbiologically induced calcium carbonate precipitation (MICP) technique. Different natural reaction is reported to form calcite such as urea hydrolysis, nitrate and sulfate reduction and finally carbonate dehydratases. There are four natural processes by which calcite is formed: carbonic anhydrase, sulphate reduction, nitrate reduction, and urea hydrolysis. Moreover, calcium lactate was reported as a nutrient for bacteria in the presence of oxygen and moisture will be converted into calcite.

\section{Biotoxicity}

The most reported method in which toxic ammonia is released uses microbially induced calcium carbonate precipitation through 
urea hydrolysis [5]. This kind of gases released during metabolic activity of bacteria are harmful to respiratory system in human being. Moreover, the effect of urea and lactate salts on concrete is not well documented. The elevated cost, the variable rate of deposition and optimum working temperature made this technique unfeasible [6]. The influence of bacterial application in concrete and its effect on the ecosystems should be well covered from different prospects.

\section{Conclusion}

Adopting new techniques should be evaluated from different ecosocial economic prospects. Bacteriologists are important players in the application of such technique when becomes in contact with living organisms.

\section{References}

1. SK Ramachandran, V Ramakrishnan, SS Bang (2001) Remediation of concrete using micro-organisms. ACI Mater J 98(1): 3-9.
2. YS Lee, W Park (2018) Current challenges and future directions for bacterial self-healing concrete. Appl Microbiol Biotechnol 102(7): 30593070 .

3. S Han, EK Choi, W Park, Ch Yi, N Chung (2019) Effectiveness of expanded clay as a bacteria carrier for self-healing concrete. Appl Biol Chem 62(19).

4. S Dinesh, R Shanmugapriyan, STN Sheen (2017) A Review on Bacteria-Based Self-Healing Concrete. Imperial Journal of Interdisciplinary Research (IJIR) 3(1): 1023-1026.

5. M Ponraj, A Talaiekhozani, RM Zin, M Ismail, MZ Abd Majid, et al. (2015) Bioconcrete Strength, Durability, Permeability, Recycling and Effects on Human Health: A Review. Intl Conf Advances in Civil. Structural and Mechanical Eng p. 1-9.

6. SS Pawar, SR Parekar (2018) Bacteria based Self-Healing Concrete: Review. International Research Journal of Engineering and Technology (IRJET) 5(3): 1001-1004. 